\title{
Determination of Ketosis with Breath Acetone Measurement Sensor on Ketogenic Diet: A Prospective Controlled Study
}

Ketojenik Diyette Nefes Aseton Ölçüm Sensörüyle Ketozisin Belirlenmesi: Prospektif Kontrollü Bir Çalışma

\begin{abstract}
Objective: Ketogenic diet may be effective in the treatment of neurological diseases such as epilepsy. Breath acetone measurement can be a practical method in the tracking of ketogenic diet treatment. This study aimed to determine the correlation between breath acetone levels and urinary ketone levels of adult individuals undergoing ketogenic diet therapy.

Materials and Methods: A total of 18 adults, which included 10 adults in the treatment group and 8 adults in the control group, were enrolled in the study. Ketogenic diet therapy was applied to the intervention group for 1 week. For 1 week, breath acetone measurements of both the treatment group and control group were taken every day at the same time on fasting. In all participants, urine ketones were measured at the same time every day.

Results: Breath acetone and urine ketone values on days 3-5 were significantly higher in the treatment group than that in the control group. Positive correlations were found between breath acetone levels and urine ketone levels in the treatment group in all 7 days.

Conclusion: The breath acetone measurement method can be used practically and reliably for ketone monitoring in individuals undergoing ketogenic diet therapy.
\end{abstract}

Keywords: Breath acetone, ketone, ketogenic diet, nanotechnology

$\ddot{O} \mathbf{z}$

Amaç: Epilepsi gibi nörolojik hastalıkların tedavisinde ketojenik diyetin etkili olabileceği düşünülmektedir. Ketojenik diyet tedavisinin takibinde nefes aseton ölçümü pratik bir yöntem olarak ön plana çıkmaktadır. Bu çalışmada, ketojenik diyet tedavisi alan yetişkin bireylerin nefes aseton düzeyleri ile idrar keton düzeyleri arasındaki ilişkinin belirlenmesi amaçlanmıştır.

Gereç ve Yöntem: Çalışmaya tedavi grubunda 10 yetişkin ve kontrol grubunda 8 yetişkin olmak üzere toplam 18 yetişkin dahil edilmiştir. Müdahale grubuna bir hafta süreyle ketojenik diyet tedavisi uygulanmıştır. Bir hafta boyunca, hem müdahale grubu hem de kontrol grubunun nefes aseton ölçümleri her gün aynı saatte aç karnına alınmış ve tüm katılımcıların idrar keton ölçümleri her gün aynı saatte yapılmıştır.

Bulgular: Müdahale grubunda 3., 4. ve 5. günlerde nefes aseton ve idrar keton değerleri kontrol grubuna göre anlamlı olarak yüksek bulunmuştur. Müdahale grubundaki nefes aseton seviyeleri ile idrar keton seviyeleri arasındaki ilişki incelendiğinde 7 günün tamamında pozitif korelasyonlar belirlenmiştir.

Sonuç: Ketojenik diyet tedavisi gören bireylerin keton takibinde nefes aseton ölçüm yönteminin pratik ve güvenilir olarak kullanılabileceği tespit edilmiştir. Anahtar Kelimeler: Nefes asetonu, keton, ketojenik diyet, nanoteknoloji

Address for Correspondence/Yazışma Adresi: Tuğçe Özlü Asst., Bahcesehir University Faculty of Medicine, Department of Nutrition and Dietetics, Istanbul, Turkey

Phone: +90 5434461770 E-mail: dyt.tugceozlu@gmail.com ORCID: orcid.org/0000-0002-0139-676X

Received/Geliș Tarihi: 12.02.2021 Accepted/Kabul Tarihi: 11.06 .2021

${ }^{\circ}$ Copyright 2021 by Turkish Neurological Society

Turkish Journal of Neurology published by Galenos Publishing House. 


\section{Introduction}

Ketogenic diet was first discovered in the 1920s, and it was thought that ketosis in dieting individuals may be effective in some diseases, especially drug-resistant epilepsy (glucose transporter protein 1 deficiency and mental and neurological diseases) $(1,2)$. In recent years, ketogenic diet, which was used as an anticonvulsant therapy for drug-resistant epilepsy, has become popular in weight control. Basically, ketogenic diet contains high fat, low carbohydrates, and protein. Among the types, the most common type is the high-fat low-carbohydrate ketogenic diet (3). While the fat content of this diet, which is defined as the classical ketogenic diet, constitutes $80-90 \%$ of the energy, carbohydrates and proteins constitute $10-20 \%(4,5)$.

In individuals who follow a ketogenic diet, ketone levels in urine and blood are measured to evaluate the state of ketosis. The American Diabetes Association reported that urine and blood ketone measurements are standard in diagnosis and evaluation (6). Urine acetone/acetoacetate detection method is also preferred because it is more practical and non-invasive than detecting betahydroxybutyrate in the blood $(7,8,9)$. However, 24-h urine collection is a difficult process. Urine dipstick analysis, which is another method, is less invasive but also less reliable (10). Additionally, in the case of dehydration, the value of urine ketone analysis may be limited in the evaluation of ketosis (11). In a study of adult individuals following a ketogenic diet, betahydroxybutyrate levels measured using breath sensors were correlated with the levels detected in the blood and urine (12). Breath acetone analysis is another method used to detect acetone, as acetone leaves the body through the lungs (13). The breath acetone measurement method can also be used to monitor weight control as an indicator of body fat loss. In recent years, the measurement of the amount of acetone in breath was reliable in determining the degree of ketosis (14).

From a clinical point of view, the measurement of breath acetone levels is important, but some limitations are noted, such as the storage of samples, standardization of clinical settings, challenges in using clinical devices, and costs of these devices. Sensors will become an important tool for the detection of breath acetone in the future given their small size and low price (12). Until now, studies of the accuracy of breath acetone sensors have been inadequate (15). Thus, this study aimed to evaluate the effectiveness of breath acetone measurement using a portable and economical sensor in determining ketosis in short-term ketogenic diet. The effects of the short-term ketogenic diet on weight loss and ketosis were also examined in a control group.

\section{Materials and Methods}

\section{Participants}

Approval was obtained from the ethics committee of Bahcesehir University Clinical Research Ethics Committee (decision no: 2019-12/04) was obtained for the study, and procedures were performed according to the ethics standards of the Helsinki Declaration. Informed consent was obtained from the participants. The study included 18 individuals, of which 10 were included in the treatment group and 8 in the control group. Individuals aged $<18$ and $>65$, those who exercise heavily, those who have chronic disease (hypertension, diabetes, kidney, liver diseases, etc.), and/or those who use regular medications were excluded from the study. The control group consisted of eight adults whose age, gender, and anthropometric measurements were matched with those of the treatment group.

\section{Study Plan}

A ketogenic diet list was created by the faculty of nutrition and dietetics and administered to the participants in the treatment group for a total of 1 week. The energy contents of the diet applied to men and women were $1200 \mathrm{kcal}$ (13\% carbohydrate, $21 \%$ protein, $64 \%$ fat) and $1100 \mathrm{kcal}(10 \%$ carbohydrate, $22 \%$ protein, $68 \%$ fat), respectively. Urine ketone and breath acetone measurements were obtained from the treatment group for 5 days, as well as from the control group not on a ketogenic diet.

\section{Anthropometric Measurements}

The body compositions of the participants were determined by bioelectrical impedance analysis at the beginning and end of the study. All measurements were made in the anthropometry laboratory of the nutrition and dietetics department. Height $(\mathrm{cm})$ was measured using a stadiometer (Leicester Height Measure, Seca 214, UK). Body composition data [weight ( $\mathrm{kg})$, body mass index (BMI; $\mathrm{kg} / \mathrm{m}^{2}$ ), fat mass $(\mathrm{kg})$, body fat ratio (\%)] was obtained by bioimpedance analysis using Inbody 270 (InBody USA, Cerritos, CA, USA). Waist circumference $(\mathrm{cm})$ was measured using a nonstretching measuring tape.

\section{Breath Acetone and Urine Ketone Measurements}

Breath acetone measurements of both the treatment and control groups were taken at the same time every day and when the individuals were fasted. Avokadio Ketone Testing Kit (Mp303a; semi-conductor metal oxide gas sensor) was used for the measurement of breath acetone levels. This semi-conductor metal oxide-based gas sensor obtained by nanotechnology has been preferred because of its advantages such as fast and precise detection, portability, and low cost compared with other traditional techniques (16). Breath gases react with the sensor and change the sensor resistance, while the changing resistance value indicates the gas concentration. To increase the accuracy of breath measurements, each measurement was applied three times and averaged.

In all participants, urine ketone levels were measured using the Laboquick urine strip at the same time of the day with breath measurement. The color of the reagent tip of the strip changed following contact with urine. The resulting colors were evaluated 15-30 s after the reaction compared with the color chart supplied with the product.

\section{Statistical Analysis}

All analyses were performed in SPSS software (version 21.0, IBM Corp., Armonk, NY, USA). Significance was accepted as $\mathrm{p}<0.05$ in all analyses. Descriptive statistics include mean and standard deviation values. The Wilcoxon test was performed for the difference between repeated measurements. The Mann-Whitney $\mathrm{U}$ test was used for the comparison of independent groups, and the Spearman correlation test was used for those variables that constantly changed. 


\section{Results}

A total of 18 adults, specifically 16 women and 2 men with a mean age of $27.5 \pm 4.4$ years, were included in this study. No significant differences were found in age and anthropometric measurements between the intervention and control groups at the beginning of the study, and the two groups were homogeneous. Following the 7 -day ketogenic diet program implemented in the intervention group, significant reductions were observed in weight $(\mathrm{p}=0.005)$, BMI $(\mathrm{p}=0.007)$, waist circumference $(\mathrm{p}=0.020)$, fat mass $(\mathrm{p}=0.005)$, and body fat ratio $(\mathrm{p}=0.066)$ (Table 1$)$.

Breath and urine measurements of the intervention group for 7 days and the control group for 5 days are shown in Table 2. On day 1 of the ketogenic diet intervention, no significant difference was noted between the groups ( $p>0.05)$; on day 2 , significant difference was only detected in the measurement of breath acetone $(\mathrm{p}<0.05)$.
However, measurements at days 3-5 were significantly higher in the treatment group than in the control group $(\mathrm{p}<0.05)$. Changes in the breath acetone and urine ketone levels of the intervention group following the ketogenic diet are also summarized in Figure 1.

In all 7 days, significant correlations were found between breath acetone levels and urine ketone levels in the intervention group $(\mathrm{p}<0.05)$. On days 4 and 5 , positive moderate correlations were observed; on other days, a high level of positive correlations were observed $(\mathrm{p}<0.05)$ (Table 3$)$.

\section{Discussion}

Ketogenic diet is a diet model that contains high amounts of fat, low amounts of carbohydrates, and sufficient amounts of protein (17). It is an effective non-pharmacological treatment method for Table 1. Change in anthropometric measurements in the intervention and control groups

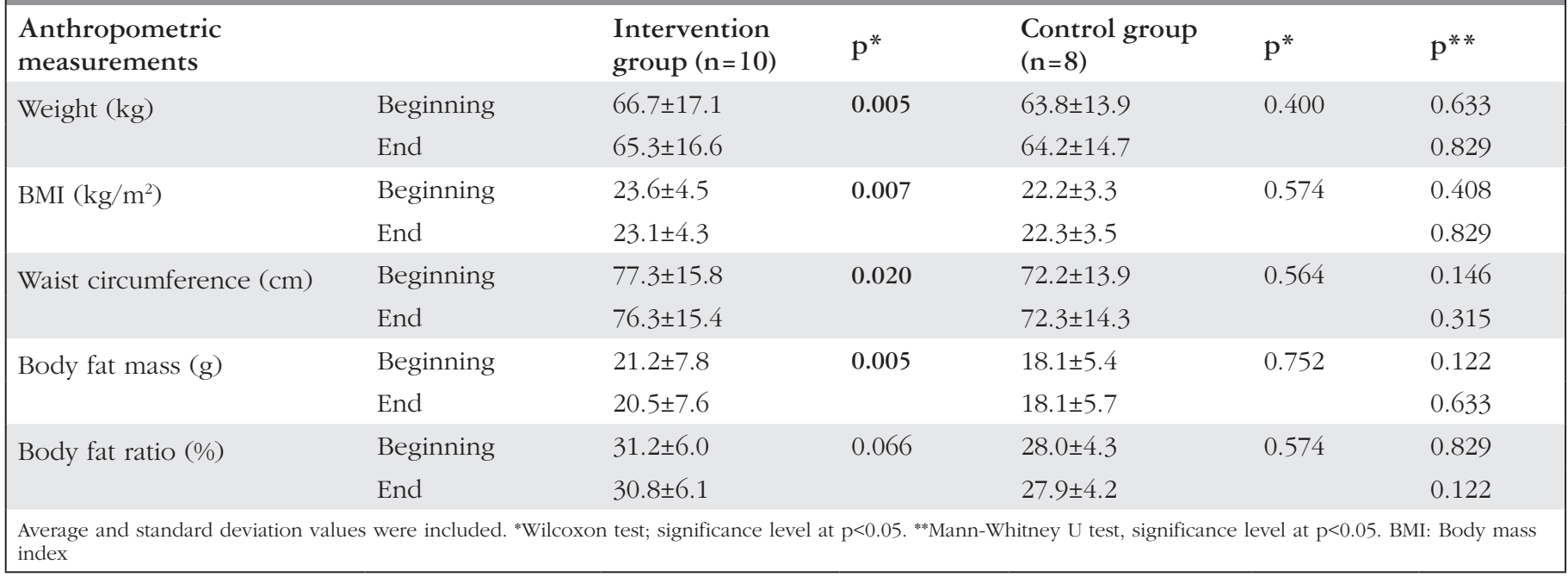

Table 2. Distribution of breath acetone and urine ketone levels by groups

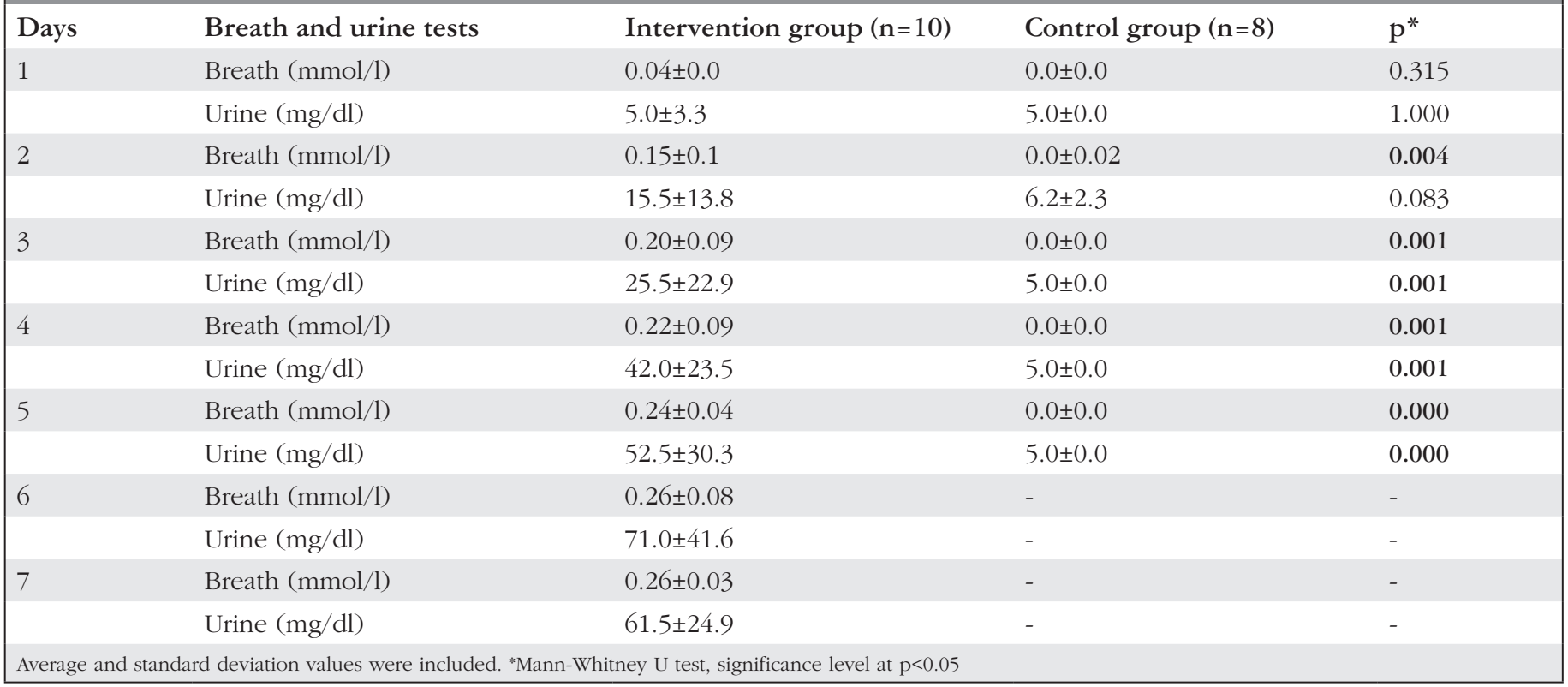




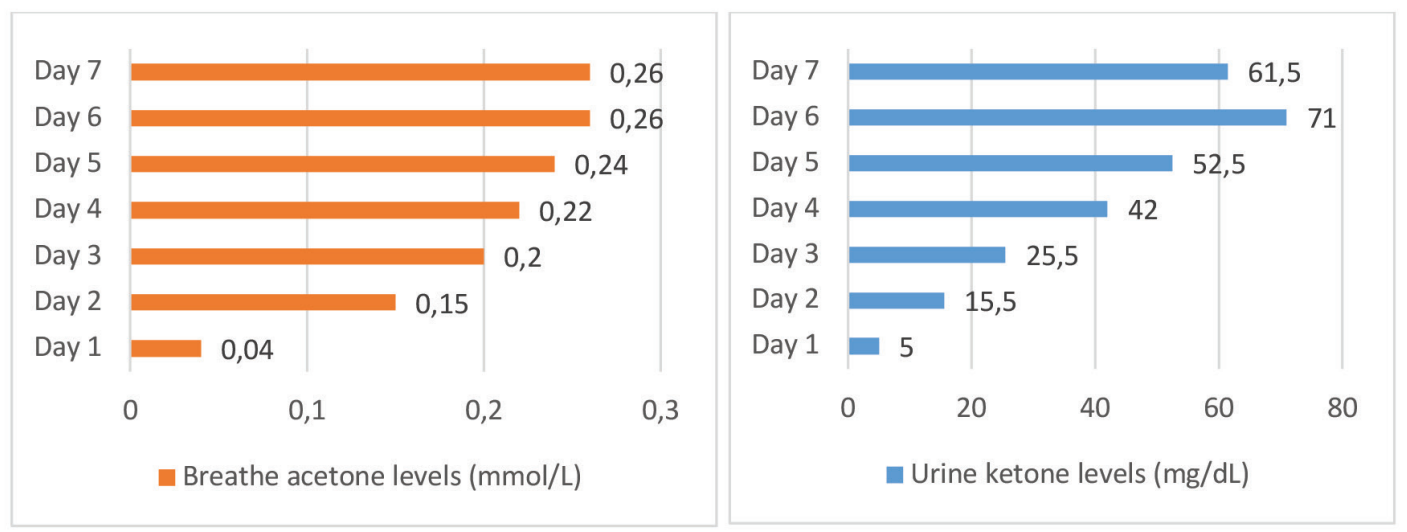

Figure 1. Distribution of breath acetone and urine ketone levels in the intervention group

Table 3. Relationship between breath acetone and urine ketone levels in the intervention group

\begin{tabular}{|c|c|c|c|c|c|c|c|c|}
\hline & & 1 & 2 & 3 & 4 & 5 & 6 & 7 \\
\hline \multirow{2}{*}{ Correlation } & $\mathrm{r}$ & 0.745 & 0.710 & 0.854 & 0.641 & 0.697 & 0.869 & 0.868 \\
\hline & $\mathrm{p}^{*}$ & 0.013 & 0.021 & 0.002 & 0.046 & 0.025 & 0.001 & 0.001 \\
\hline
\end{tabular}

patients with "drug-resistant epilepsy" (18). In addition, the use of ketogenic diet in the management of diseases such as obesity and type 2 diabetes has been discussed in recent years $(19,20)$. In a meta-analysis of 13 studies that examined the long-term effects of very low-carbohydrate ketogenic diets on weight loss, very lowcarbohydrate ketogenic diets caused significantly higher degree of weight loss than low-fat diets $(\mathrm{p}=0.02)(20)$. Similar to literature findings, in our study, anthropometric measurements were significantly lower in the ketogenic diet group after treatment. Despite the consistent results, considering the long-term possible side effects of a ketogenic diet, it is important to set the diet correctly, determine the duration of the diet, and have regular follow-ups (21).

Ketone bodies are mainly produced by ketogenesis in the mitochondrial matrix of liver cells and then exported to other organs to meet the energy demands of cells in the body through the blood (17). After a few days of fasting or carbohydrate-restricted ( $<20 \mathrm{~g} /$ day) diet, the body's glucose reserves become insufficient for normal fat oxidation and glucose supply to the central nervous system. The central nervous system requires an alternative energy source other than glucose, which leads to the production of ketone bodies such as acetoacetate, hydrohydroxybutyric acid, and acetone. These increasing levels of ketone bodies in the blood are removed from the body through urine and respiration (21). In the case of ketoacidosis, John Rollo (22) first determined in 1978 that individuals smelled of acetone when breathing and that this condition may be a symptom of ketoacidosis. Measurement of these ketone bodies provides information about the presence and severity of ketoacidosis. Breath acetone and urine ketone measurement methods are used to measure ketone bodies. However, breath acetone measurement was found to be more reliable than urine ketone measurement (10).
Given the advancements in modern measurement technologies, breath measurements provide a non-invasive method for disease diagnosis and monitoring of metabolic status (23). In a study of individuals with type 2 diabetes $(n=58)$, a significant relation was found between breath acetone and blood acetoacetate levels $(\mathrm{r}=0.89)$ and $\beta$-hydroxybutyrate $(\mathrm{r}=0.82)$ (24). In another study of individuals with diabetes $(n=99)$, breathe acetone levels correlated with blood and urine ketone levels in the case of ketosis, and breath sensors were found to be reliable for use in diabetic ketoacidosis (25). Prabhakar et al. (26) showed that methods of measuring breath acetone levels are more effective than blood and urine methods in the early detection of ketosis. Another study reported that safety of measuring acetone levels in adults $(n=11)$ on received classical ketogenic diet (27). These results showed the effectiveness of using breath sensors in determining/monitoring ketone levels. In most of these studies, breath acetone levels were measured using methods such as gas chromatography with mass spectrometry/flame-ionization detection and selected ion flow tube mass spectrometry $(24,25,26)$. Despite their extremely high levels of sensitivity, these clinical tools do not allow self-monitoring because of their size, cost, and need for trained personnel (15). In our study, we found a correlation between urine ketone levels and breath acetone levels measured by semi-conductor metal oxide gas sensor technology. The rapid progress in nanotechnological semi-conductor technologies has made it easier to measure breath components (28). Non-invasive technologies, more especially the nanosensor breath technologies which are portable, cheap to fabricate, highly sensitive, and easy to use, have potential in the measurement of volatile gases such as acetone and carbon dioxide $(28,29)$. In this context, since the method of determining ketone levels in the blood is invasive and difficult to reach, measurement 
and monitoring of ketone levels with breath sensors become important.

In contrast to our study, most studies enrolled individuals with diabetes $(24,25)$. Considering that many factors (such as stress, exercise, and drug use) other than dietary factors affect ketosis in individuals with diabetes, our participants were healthy, did not exercise, and did not use drugs. In addition, in our study, no significant difference was observed in the anthropometric measurements of the control and treatment groups at the beginning of the study. This situation minimizes environmental factors other than diet that affect individuals' ketosis status.

\section{Study Limitations}

This study has some limitations. First, the sample size was relatively low. Second, blood ketone levels, which are more reliable, could not be measured and compared with breath measurements. Thus, breath acetone levels were compared only with urine ketone levels. Despite these limitations, this study will contribute to the literature by evaluating the accuracy of breath acetone measurement among individuals on ketogenic diet.

\section{Conclusion}

In our study, acetone levels correlated with urine ketone levels in individuals on a ketogenic diet, and breath acetone levels proved to be a suitable biomarker for monitoring ketosis. Given the longterm possible side effects of a ketogenic diet, regular follow-ups are important during the course of the diet. Breath acetone test can be used in the follow-up of ketosis because of its non-invasive nature, easy application, and reliability. In this study, we emphasized that the use of nanosensors in measuring breath acetone level is more reliable and useful than the urine method. Ketogenic diets are also important for patients with epilepsy and diabetes to attain a practically weakened state of ketosis. In the future, additional studies conducted on various patient groups (epilepsy and other diseases related with ketogenic diet) will provide more information about the clinical utility of breath acetone sensors.

\section{Acknowledgments}

We would like to thank Avokadio for their support on the use of sensor.

\section{Ethics}

Ethics Committee Approval: Approval was obtained from the ethics committee of Bahcesehir University Clinical Research Ethics Committee (decision no: 2019-12/04) was obtained for the study, and procedures were performed according to the ethics standards of the Helsinki Declaration.

Informed Consent: Informed consent was obtained from the participants

Peer-review: Externally peer-reviewed.

\section{Authorship Contributions}

Concept: G.G., Design: G.G., Data Collection or Processing: B.M.K., T.Ö., Analysis or Interpretation: G.G., B.M.K., T.Ö., Literature Search: G.G., B.M.K., T.Ö., Writing: G.G., B.M.K., T.Ö.

Conflict of Interest: G.G. acts as consultant to Avokadio. Avokadio had no role in the design of the study; in the interpretation of data; in the writing of the manuscript, or in the decision to publish the results.
Financial Disclosure: The authors declared that this study received no financial support.

\section{References}

1. Wheless JW. History of the ketogenic diet. Epilepsia 2008;49(Suppl 8):3-5.

2. Brietzke E, Mansur RB, Subramaniapillai M, et al. Ketogenic diet as a metabolic therapy for mood disorders: Evidence and developments. Neurosci Biobehav Rev 2018;94:11-16.

3. Walczyk T, Wick JY. The Ketogenic Diet: Making a Comeback. Consult Pharm 2017;32:388-396.

4. Ułamek-Kozioł M, Czuczwar SJ, Januszewski S, Pluta R. Ketogenic Diet and Epilepsy. Nutrients 2019;11:2510.

5. Carel RS, Silverberg DS, Kaminsky R, Aviram A. Routine urinalysis (dipstick) findings in mass screening of healthy adults. Clin Chem 1987;33:2106-2108.

6. Sacks DB, Arnold M, Bakris GL, et al. Guidelines and recommendations for laboratory analysis in the diagnosis and management of diabetes mellitus. Diabetes Care 2011;34:e61-99.

7. Vanelli M, Mastrorilli C, Fainardi V, et al. Clinical utility of betahydroxybutyrate measurement in the management of physiological ketosis at home in children under 5. Acta Biomed 2019;90:215-220.

8. Mitchell R, Thomas SD, Langlois NE. How sensitive and specific is urinalysis 'dipstick' testing for detection of hyperglycaemia and ketosis? An audit of findings from coronial autopsies. Pathology 2013;45:587-590.

9. Naumenko DJ, Watford M, Utami Atmoko SS, Erb WM, Vogel ER. Evaluating Ketosis in Primate Field Studies: Validation of Urine Test Strips in Wild Bornean Orangutans (Pongo pygmaeus wurmbii). Folia Primatol (Basel) 2020;91:159-168.

10. Musa-Veloso K, Likhodii SS, Cunnane SC. Breath acetone is a reliable indicator of ketosis in adults consuming ketogenic meals. Am J Clin Nutr 2002;76:65-70.

11. Misra S, Oliver NS. Utility of ketone measurement in the prevention, diagnosis and management of diabetic ketoacidosis. Diabet Med 2015;32:14-23.

12. Ruzsányi V, Péter Kalapos M. Breath acetone as a potential marker in clinical practice. J Breath Res 2017;11:024002.

13. Shokrekhodaei M, Quinones S. Review of Non-invasive Glucose Sensing Techniques: Optical, Electrical and Breath Acetone. Sensors (Basel) 2020;20:1251.

14. Anderson JC. Measuring breath acetone for monitoring fat loss: Review. Obesity (Silver Spring) 2015;23:2327-2334.

15. Suntrup Iii DJ, Ratto TV, Ratto M, McCarter JP. Characterization of a highresolution breath acetone meter for ketosis monitoring. PeerJ 2020;8:e9969.

16. Chavali MS, Nikolova MP. Metal oxide nanoparticles and their applications in nanotechnology. SN Applied Sciences 2019;1:1-30.

17. Vidali S, Aminzadeh S, Lambert B, et al. Mitochondria: The ketogenic diet-A metabolism-based therapy. Int J Biochem Cell Biol 2015;63:55-59.

18. Rezaei S, Abdurahman AA, Saghazadeh A, Badv RS, Mahmoudi M. Shortterm and long-term efficacy of classical ketogenic diet and modified Atkins diet in children and adolescents with epilepsy: A systematic review and meta-analysis. Nutr Neurosci 2019;22:317-334.

19. Goday A, Bellido D, Sajoux I, et al. Short-term safety, tolerability and efficacy of a very low-calorie-ketogenic diet interventional weight loss program versus hypocaloric diet in patients with type 2 diabetes mellitus. Nutr Diabetes 2016;6:e230.

20. Bueno NB, de Melo IS, de Oliveira SL, da Rocha Ataide T. Very-lowcarbohydrate ketogenic diet $\mathrm{v}$. low-fat diet for long-term weight loss: a meta-analysis of randomised controlled trials. Br J Nutr 2013;110:11781187

21. Paoli A. Ketogenic diet for obesity: friend or foe? Int J Environ Res Public Health 2014;11:2092-2107.

22. Rollo J. Cases of the Diabetes Mellitus with the Results of the Trials of Certain Acids, and Other Substances, in the Cure of Lues Venereal. 2nd ed. London: T. Gillet; 1798. 
23. Wang Z, Wang C. Is breath acetone a biomarker of diabetes? A historical review on breath acetone measurements. J Breath Res 2013;7:037109.

24. Saasa V, Beukes M, Lemmer Y, Mwakikunga B. Blood Ketone Bodies and Breath Acetone Analysis and Their Correlations in Type 2 Diabetes Mellitus. Diagnostics (Basel) 2019;9:224.

25. Qiao Y, Gao Z, Liu Y, et al. Breath ketone testing: a new biomarker for diagnosis and therapeutic monitoring of diabetic ketosis. Biomed Res Int 2014;2014:869186.

26. Prabhakar A, Quach A, Wang D, et al. Breath acetone as biomarker for lipid oxidation and early ketone detection. Global Journal of Obesity, Diabetes and Metabolic Syndrome 2014;1:012-019.
27. Güntner AT, Kompalla JF, Landis H, et al. Guiding Ketogenic Diet with Breath Acetone Sensors. Sensors (Basel) 2018;18:3655.

28. Wang L, Kalyanasundaram K, Stanacevic M, Gouma P. Nanosensor device for breath acetone detection. Sensor Letters 2010;8:709-712.

29. Saasa V, Malwela T, Beukes M, et al. Sensing technologies for detection of acetone in human breath for diabetes diagnosis and monitoring. Diagnostics 2018;8:12. 